\title{
Torulopsis bacarum, Torulopsis pustula and Torulopsis multis-gemmis sp. nov., Three New Yeasts from Soft Fruit
}

\author{
By R. W. M. BUHAGIAR \\ Agricultural Research Council Food Research Institute, Colney Lane, \\ Norwich NOR $70 F$
}

(Received 8 April 1974; revised 5 August 1974)

SUMMAR Y

Three new species of yeasts isolated from fresh soft fruit are described. Torulopsis pustula was isolated from blackcurrants, Torulopsis bacarum from blackcurrants, strawberries and raspberries, and Torulopsis multis-gemmis from raspberries. All differ from known species in the test substrates they utilize. In addition, cells of Torulopsis pustula often form a bulbous projection near their apices from which budding takes place. These buds are frequently pear- or heart-shaped.

\section{INTRODUCTION}

During surveys of yeasts on soft fruit carried out in 1971 and 1972 , three hitherto undescribed species were isolated, and the following names are proposed:Torulopsis pustula, 4 strains isolated from blackcurrants (Ribes nigrum cultivar Baldwin); Torulopsis multisgemmis, 20 strains isolated from raspberries (Rubus idaeus cultivar Malling Jewel); and Torulopsis bacarum, 19 strains isolated from blackcurrants (Ribes nigrum cultivar Baldwin), and 2 strains each from raspberries (Rubus idaeus cultivar Malling Jewel) and strawberries (Fragaria ananassa cultivar Cambridge Favourite). All strains were isolated from surface colonies on Difco Bacto YM agar, at (i) $\mathrm{pH} 3.4$, or (ii) $\mathrm{pH} 4.8$, or (iii) $\mathrm{pH} 6.0$ with added antibiotics, thiamin and $\mathrm{CaCO}_{3}$. Torulopsis pustula and T. bacarum were obtained from all three media, but isolations of $T$. multis-gemmis were made only from (i) or (iii). These new species are described.

\section{METHODS}

The isolation methods were those of Buhagiar \& Barnett (197I), with the modifications that incubation was at $20^{\circ} \mathrm{C}$ throughout and that further isolations were made on Difco Bacto YM agar at pH 6.0 with the addition (per ml) of $20 \mu \mathrm{g}$ streptomycin, $20 \mu \mathrm{g}$ chloramphenicol and $100 \mu \mathrm{g}$ chlortetracycline (Ross \& Morris, 1965), and of $10 \mu \mathrm{g}$ thiamin and $5 \mathrm{mg}$ reprecipitated $\mathrm{CaCO}_{3}$ (Phaff, Miller \& Mrak, I966).

Methods for examining the yeasts closely followed those described by Barnett \& Buhagiar (I97I) and Buhagiar \& Barnett (I97I). However, the rocked tubes of liquid medium used for aerobic growth tests were incubated at $20{ }^{\circ} \mathrm{C}$ for 4 weeks, and sugars obtained from Sigma were used throughout. Additional tests included the examination for pulcherrimin pigment by the method of Beijerink as modified by van der Walt (1970). The fat-splitting test according to the method of Eijkman and the test for the liquefaction of $12 \%$ gelatin (Difco Bacto) were also carried out as described by van der Walt (1970). Reactions on litmus milk (Oxoid CM45) were tested as described by Lodder \& Kreger-van Rij (I952). The method of Markovetz \& Kallio (1964) was used to test for hydrocarbon utilization. 
Growth test medium without carbon source and containing $10 \mathrm{~g}$ Ionagar No. 2 (Oxoid)/1 was made into slants. After inoculation, I $\mathrm{ml}$ of either $n$-decane or $n$-hexadecane (more than $99 \%$ pure, Koch-Light Ltd) was added to each tube. Slants of the same mineral medium without carbon source, and slants containing I $\mathrm{ml}$ of $50 \mathrm{~mm} \mathrm{D}$-glucose were used as controls. All the tubes were sealed and incubated at $20^{\circ} \mathrm{C}$, and were checked for visible growth for up to 28 days.

Malt extract broth and malt agar (van der Walt, 1970), used to study cultural characteristics, were made from unhopped malt extract obtained from a local brewery. Further morphological studies were made on $2 \%$ glucose-yeast extract-peptone-water (Difco Bacto). Media used to test for ascospore formation were those described by van der Walt (1970). All strains of each species isolated were grown individually and collectively on grape juice presporulation medium and then streaked on to carrot plugs, potato plugs, malt extract agar, gypsum blocks, McClary's acetate agar, Gorodkowa agar (modified), Difco Bacto potato-dextrose agar, and V8 vegetable-juice agar. The search for ascospores was carried out periodically for up to 6 weeks.

\section{RESULTS}

Torulopsis bacarum sp. nov.

In liquore definito cum D-glucoso, in augendo ad $25{ }^{\circ} \mathrm{C}$ cellulae oviformes, $3 \cdot$ I ad $5 \cdot 8 \times$ I. 6 ad 3.1 $\mu \mathrm{m}$. Cellulae cum gemmis singularibus aut duobus quas in aut juxta uni apice vel ambis apicibus formatae sunt. Pseudohyphae et hyphae verae non formantur. Fermentatio nulla. Ascosporae, ballistosporae non sunt. Fermenta speciei huius crescunt in liquore definito cum raffinoso, melezitoso, sucroso, maltoso, trehaloso, methyl $\alpha$-D-glucosido, cellobioso (lente), salicino (lente), D-glucoso, L-sorboso (variabile), D-riboso, D-xyloso, D-arabinoso, L-arabinoso, succinato, citrato (lente), lactato (lente), glycerolo, erythritolo, ribitolo (variabile), D-glucitolo (interdum lente), D-mannitolo, inulino (lente). Kalii nitras assimilatur. Non crescunt cum melibioso, lactoso, D-galactoso, L-rhamnoso, galactitolo, myo-inositolo, amylo. Vitaminarum addendum necessarium non est. In $30^{\circ} \mathrm{C}$ non crescunt; in $25^{\circ} \mathrm{C}$ crescunt. In $50 \% \mathrm{D}$-glucoso non crescunt. Amylum non formatur. Urea hydrolysatur. Abutinum finditur. Acidum non formatur. Sebum bovillum non finditur. Gelatinum non liquidum fit. Nec n-decanum nec n-hexadecanum non assimilantur.

Typus cultura 6526 in collectione Centraalbureau voor Shimmelcultures, Delft, ex Ribes nigrum.

\section{Cultural characteristics}

Macroscopical appearance. After 3 days at $25^{\circ} \mathrm{C}$, streak cultures on Difco Bacto YM agar were white, cream, or buff-cream, glossy or semi-glossy, smooth, soft, flat, with undulating to entire margins. After I month at $15{ }^{\circ} \mathrm{C}$, cultures were grey, cream to buff, flat, semi-glossy or matt, finely granular or pasty, with undulating to entire margins. On malt agar medium cultures were a deeper buff colour, otherwise cultural characteristics were similar to those on YM agar. A faint lilac tinge was observed with some strains growing on YM or malt agar media.

Microscopical appearance. In exponential growth in liquid medium containing D-glucose, cells were oval with single or double budding on or near one pole. Budding occurred at both poles only rarely, and chains of up to 5 cells were sometimes formed (Fig. I). Cells measured $3 \cdot I$ to $5 \cdot 8 \times \mathrm{I} \cdot 6$ to $3 \cdot \mathrm{I} \mu \mathrm{m}$ (Table I). On malt extract medium and on glucose-yeast extractpeptone-water medium, the shape and size of the cells were similar to those formed on the 


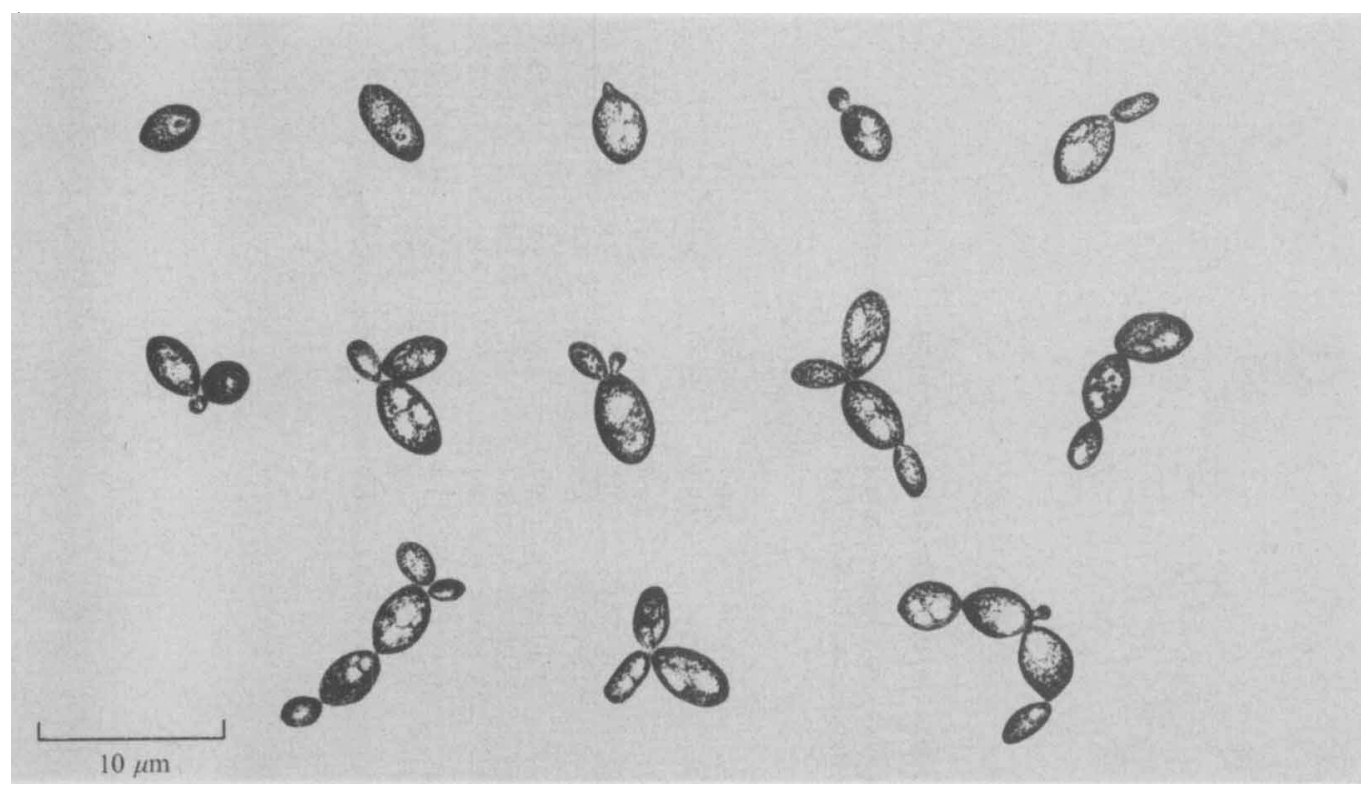

Fig. I. Drawing of $T$. bacarum made from several strains during exponential growth at $25^{\circ} \mathrm{C}$ in shaken defined liquid medium with D-glucose as sole carbon source.

D-glucose medium. With slide cultures no mycelium or pseudomycelium was formed under or outside the coverslip. No conjugation or ascospore formation was seen in individual strains or in mixtures of strains. Ballistospores were not formed.

\section{Physiological tests}

Anaerobic fermentation. In yeast water containing $50 \mathrm{mM}-\mathrm{D}$-glucose none of the strains produced gas in Durham tubes.

Aerobic growth. Most strains tested utilized L-sorbose and ribitol. However, growth was always slow and, in the case of L-sorbose, often latent. Results are given in Table 2.

Other tests. There was no starch production by cells grown on solid or liquid media; urea was hydrolysed; arbutin was split; no pulcherrimin pigment was formed. The strains grew at $25{ }^{\circ} \mathrm{C}$ but not at $30^{\circ} \mathrm{C}$. No acid was produced by any of the strains on $\mathrm{CaCO}_{3}$ plates, neither litmus milk nor fat was split, and gelatin was not liquefied. The strains did not grow on media with $50 \%(\mathrm{w} / \mathrm{v}) \mathrm{D}$-glucose, and were unable to utilize either $n$-decane or $n$-hexadecane as sole carbon sources.

One strain of T. bacarum, CBS6526 (type strain) isolated from blackcurrants, has been deposited in the collection of the Yeast Division of the Centraalbureau voor Schimmelcultures.

\section{Torulopsis pustula sp. nov.}

In liquore definito cum D-glucoso in augendo ad $25^{\circ} \mathrm{C}$ cellulae piriformae, ovatae, ovoideaeque 4.5 ad $7.8 \times 2.4$ ad $5.2 \mu \mathrm{m}$. Cellulae cum gemmis singularibus aut duobus in vel juxta uni vel ambis apicibus formantur. Sunt cellulae cum protuberationibus in vel juxta apicibus; 


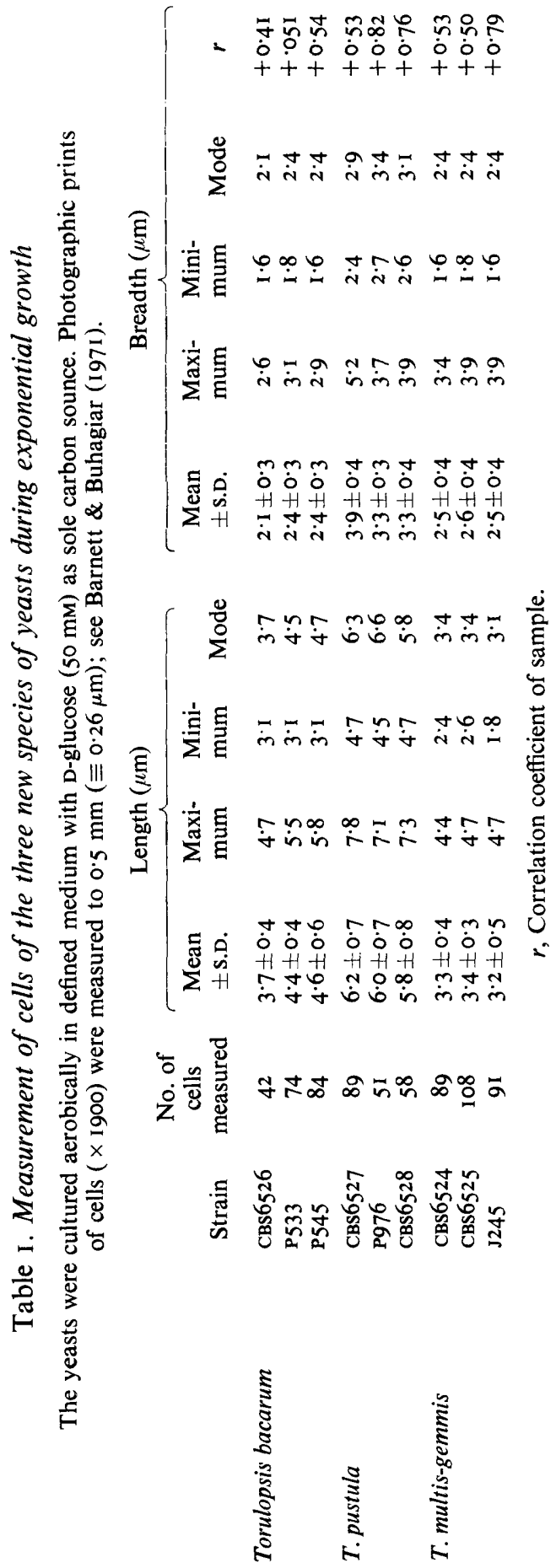




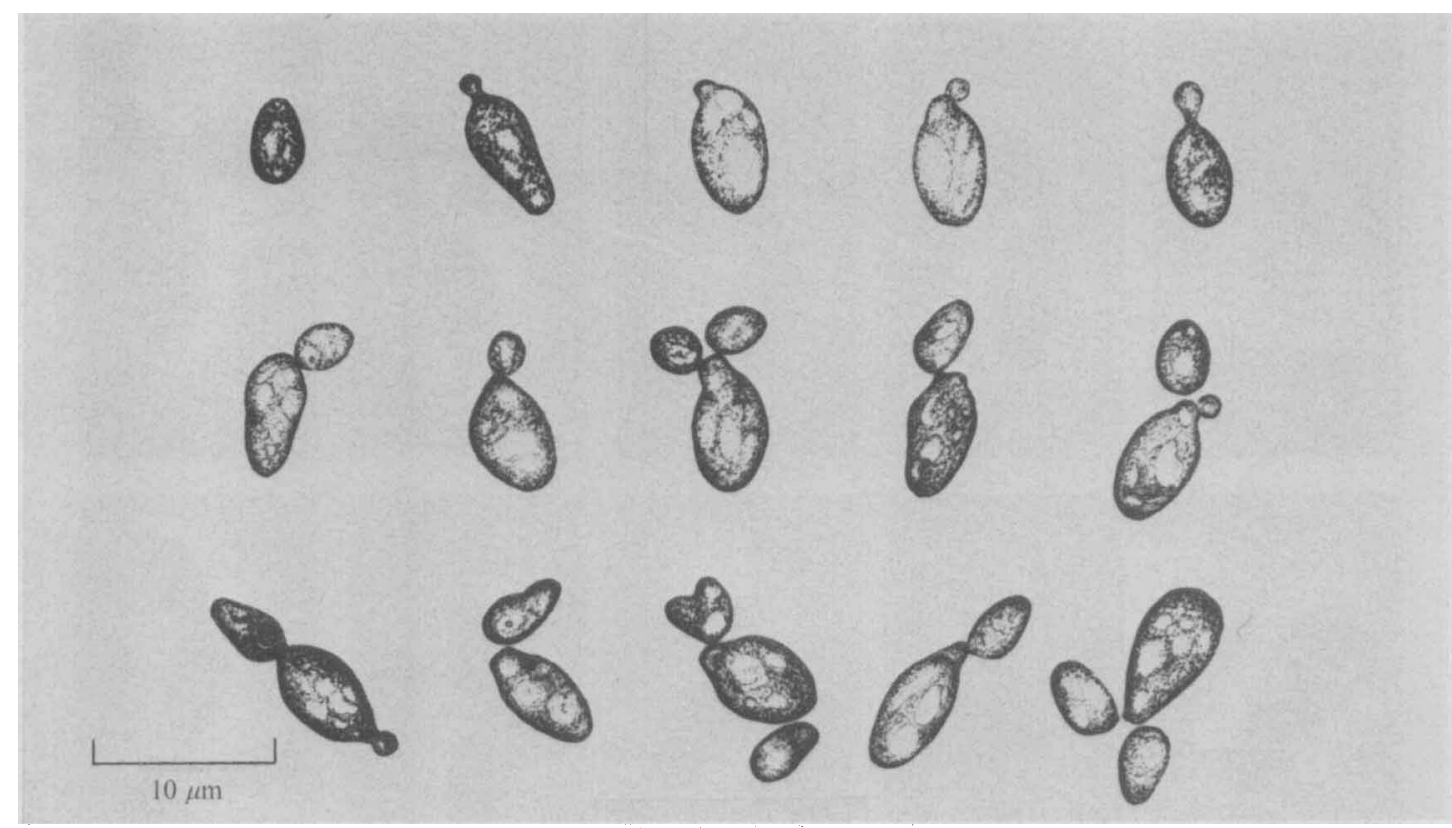

Fig. 2. Drawings of Torulopsis pustula made from several strains during exponential growth at $25^{\circ} \mathrm{C}$ in shaken defined liquid medium with D-glucose as sole carbon source.

ex his protuberationibus gemmae formantur. Gemmae sunt in forma vel ellipses vel piriformae, interdum ad cordis speciem factae. Pseudohyphae et hyphae verae non formantur. Fermentatio nulla. Ascosporae, ballistosporae non sunt. Fermenta speciei huius crescunt in liquore definito cum trehaloso, cellobioso, salicino, D-glucoso, D-galactoso (variabile), L-sorboso, D-riboso, D-xyloso, D-arabinoso, L-arabinoso, succinato, citrato, glycerolo (lente), ribitolo, D-glucitolo, D-mannitolo. Kalli nitras assimilatur. Non crescunt cum raffinoso, melezitoso, sucroso, maltoso, methyl $\alpha$-D-glucosido, melibioso, lactoso, L-rhamnoso, lactato, erythritolo, galactitolo, myoinositolo, amylo, inulino. Vitaminarum addendum necessarium est. In $30^{\circ} \mathrm{C}$ non crescunt; in $25{ }^{\circ} \mathrm{C}$ crescunt. In $50 \%$ D-glucoso non crescunt. Amylum non formatur. Sebum bovillum non finditur. Gelatinum non liquidum fit. Urea hydrolysatur. Arbutinum finditur. n-Decanum et n-hexadecanum assimilantur (tardum). Acidum non formatur.

Typus cultura 6527 in collectione Centraalbureau voor Schimmelcultures, Delft, isolata ex Ribes nigrum.

\section{Cultural characteristics}

Macroscopical appearance. After 3 days at $25{ }^{\circ} \mathrm{C}$, streak cultures on Difco Bacto YM agar were white or white-cream, mucoid, glossy, smooth, soft, runny, raised, with margins entire. After I month at $15{ }^{\circ} \mathrm{C}$, cultures were cream, glossy, soft, highly mucoid, runny, smooth, with entire margins. On malt agar, cultural characteristics were similar to those on YM agar.

Microscopical appearance. In exponential growth in liquid defined medium containing D-glucose, cells were oval, ovoid or pear-shaped, with one or two buds formed on or near one pole. Less frequently buds were formed at both poles. Budding often took place on bulbous projections which were frequently laterally inclined and were formed near the poles. These buds were elliptical to pear-shaped and occasionally heart-shaped (Fig. 2). Cells 


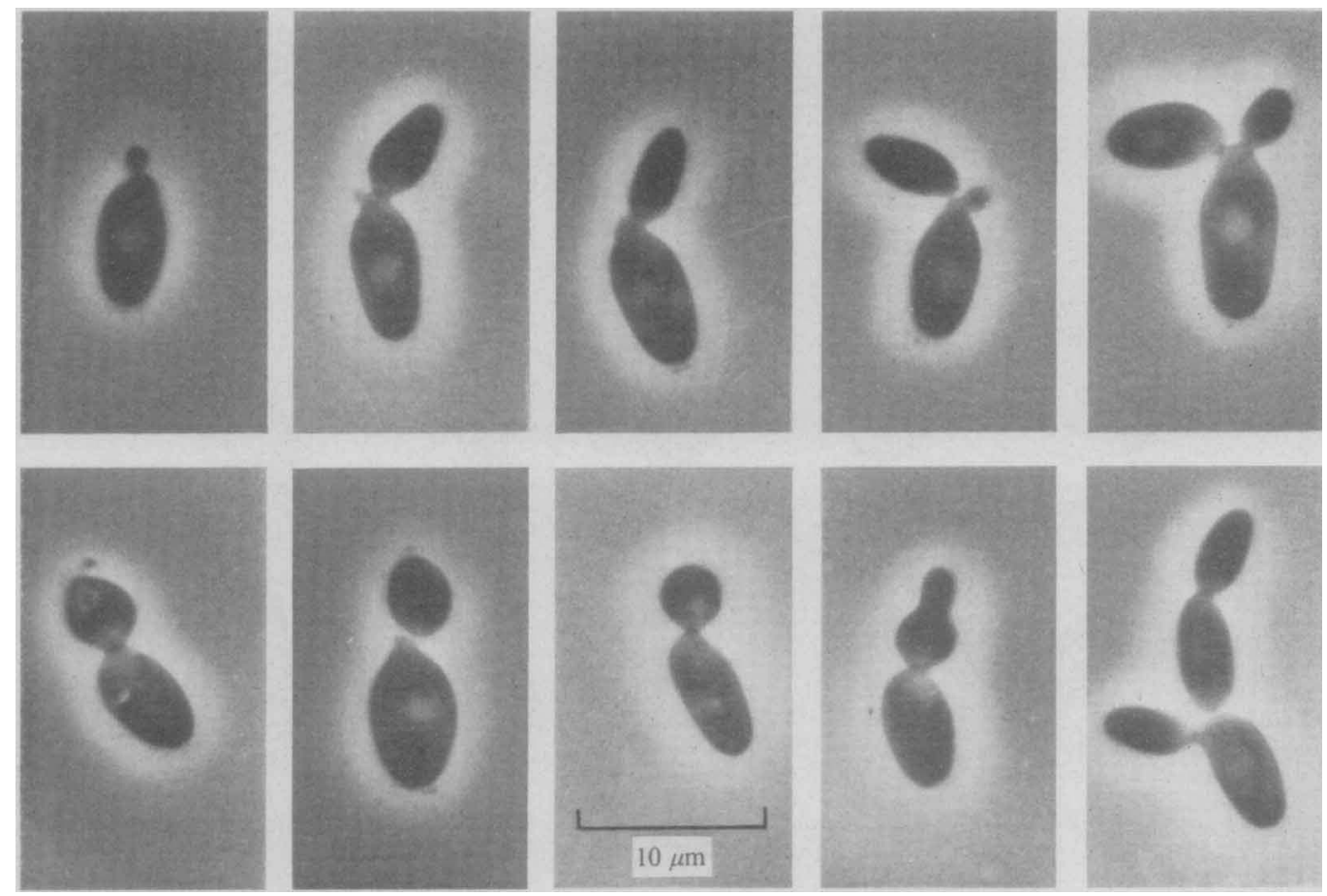

Fig. 3. Photomicrographs of $T$. pustula (CBS6527) showing bud formation at different stages. Culture in unshaken glucose-yeast extract-peptone-water after 3 days of incubation at $25^{\circ} \mathrm{C}$. Leitz phase contrast (Heine).

measured 4.5 to $7 \cdot 8 \times 2 \cdot 4$ to $5.2 \mu \mathrm{m}$ (Table 1 ). On malt extract medium and on glucose-yeast extract-peptone-water medium (Fig. 3), cells appeared similar to those formed on the Dglucose medium although no heart-shaped buds were seen.

With slide cultures no mycelium or pseudomycelium was formed under or outside the coverslip. No conjugation or ascospore formation was observed with individual strains or with mixtures of strains. Ballistospores were not formed.

\section{Physiological tests}

Anaerobic fermentation. In yeast water containing $50 \mathrm{~mm}$ D-glucose none of the strains produced gas in Durham tubes.

Aerobic growth. Results are given in Table 2. Three strains of the four tested utilized galactose and growth was always latent (see footnote, Table 2). On the D-glucose defined liquid medium without added vitamins growth was generally absent, although occasionally weak growth was recorded.

Other tests. No starch was produced by cells grown on either liquid or solid media; urea was hydrolysed; arbutin was split; no pulcherrimin pigment was formed. The strains grew at $25^{\circ} \mathrm{C}$ though not at $30^{\circ} \mathrm{C}$. No acid was produced by cells grown on $\mathrm{CaCO}_{3}$ plates; neither fat nor litmus milk was split, and gelatin was not liquefied. The strains did not grow on media with $50 \%(\mathrm{w} / \mathrm{v}) \mathrm{D}$-glucose, but $n$-decane and $n$-hexadecane were both utilized as sole carbon sources although visible growth was delayed for 14 days. 
Table 2. Results of aerobic growth tests for the three new species of yeasts

\begin{tabular}{|c|c|c|c|}
\hline Substrate & T. bacarum & $T \cdot$ pustula & $\begin{array}{c}T . \text { multis } \\
\text { gemmis }\end{array}$ \\
\hline Raffinose & + & - & - \\
\hline Melezitose & + & - & + or $\mathbf{s}$ \\
\hline Sucrose & + & - & + \\
\hline Maltose & + & - & + \\
\hline Trehalose & + & + & + \\
\hline Methyl $\alpha$-D-glucoside & + & - & - \\
\hline Cellobiose & $\mathbf{S}$ & + & - \\
\hline Salicin & $\mathbf{s}$ & + & - \\
\hline Melibiose & - & - & - \\
\hline Lactose & - & - & - \\
\hline D-Glucose & + & + & + \\
\hline D-Galactose & - & $\mathrm{v}$ & + \\
\hline L-Sorbose & $v$ & + & + \\
\hline L-Rhamnose & - & - & - \\
\hline D-Ribose & + & + & $\mathbf{L}$ \\
\hline D-Xylose & + & + & + or $s \dagger$ \\
\hline D-Arabinose & + & + & - \\
\hline L-Arabinose & + & + & + or $\mathrm{s}$ \\
\hline Succinate & + & + & + \\
\hline Citrate & + or - & + & + \\
\hline Lactate & $\mathrm{s}$ & - & - \\
\hline Glycerol & + & $\mathbf{s}$ & $\mathbf{s}$ \\
\hline Erythritol & + & - & - \\
\hline Ribitol & $\mathrm{v}$ & + & + \\
\hline D-Glucitol & + or $\mathbf{s}$ & + & + \\
\hline D-Mannitol & + & + & - \\
\hline Galactitol & - & - & - \\
\hline myo-Inositol & - & - & - \\
\hline Starch & $-{ }^{*}$ & - & - \\
\hline Inulin & $\mathbf{s}$ & - & - \\
\hline $\mathrm{KNO}_{3}$ & + & + & - \\
\hline $\begin{array}{l}\text { D-Glucose without } \\
\text { vitamin addition }\end{array}$ & + or $w$ & - & - \\
\hline
\end{tabular}

+ , Growth was more than $0.4 \mathrm{mg}$ dry wt/ml within 7 days; - , no growth after 4 weeks; s, growth did not reach $0.4 \mathrm{mg}$ dry wt/ml until after 7 days (cf. Buhagiar \& Barnett, 197I); w, growth reached $0.05 \mathrm{mg}$ dry $\mathrm{wt} / \mathrm{ml}$ within 7 days but no more than $0.2 \mathrm{mg}$ dry wt $/ \mathrm{ml}$ within 28 days; $\mathrm{L}$, growth only after $2 \mathrm{I}$ days; $\mathrm{v}$, variable results obtained with different strains.

* D. Yarrow (personal communication, 1973) reported growth with soluble starch (Difco).

† One strain did not grow.

Two strains of T.pustula, CBS6527 (type strain) and CBS6528, have been deposited in the collection of the Yeast Division of the Centraalbureau voor Schimmelcultures. Both strains were isolated from blackcurrants.

Torulopsis multis-gemmis sp. nov.

In liquore definito cum D-glucoso in augendo ad $25^{\circ} \mathrm{C}$ cellulae spheroidales vel ovoideae, raro cylindricae breves $\mathrm{I} \cdot 8$ ad $4.7 \times \mathrm{I} .6$ ad $3.9 \mu \mathrm{m}$; singulae, binae, in catenis brevis aut in racemis parvis. Gemmae multilaterales crescunt. Cellulae cum quot multis tot septem gemmis formatae sunt. Pseudohyphae et hyphae verae non formantur. D-glucosum fermentatur (exigue, interdum tardum) at non sucrosum, maltosum, trehalosum, melibiosum, lactosum nec Dgalactosum. Neque ascosporae neque ballistosporae sunt. Fermenta speciei huius crescunt in liquore definito cum melezitoso (interdum lente), sucroso, maltoso, trehaloso, D-glucoso, $\mathrm{D}$-galactoso, L-sorboso, D-riboso (tarde), D-xyloso (interdum lente), L-arabinoso (interdum 


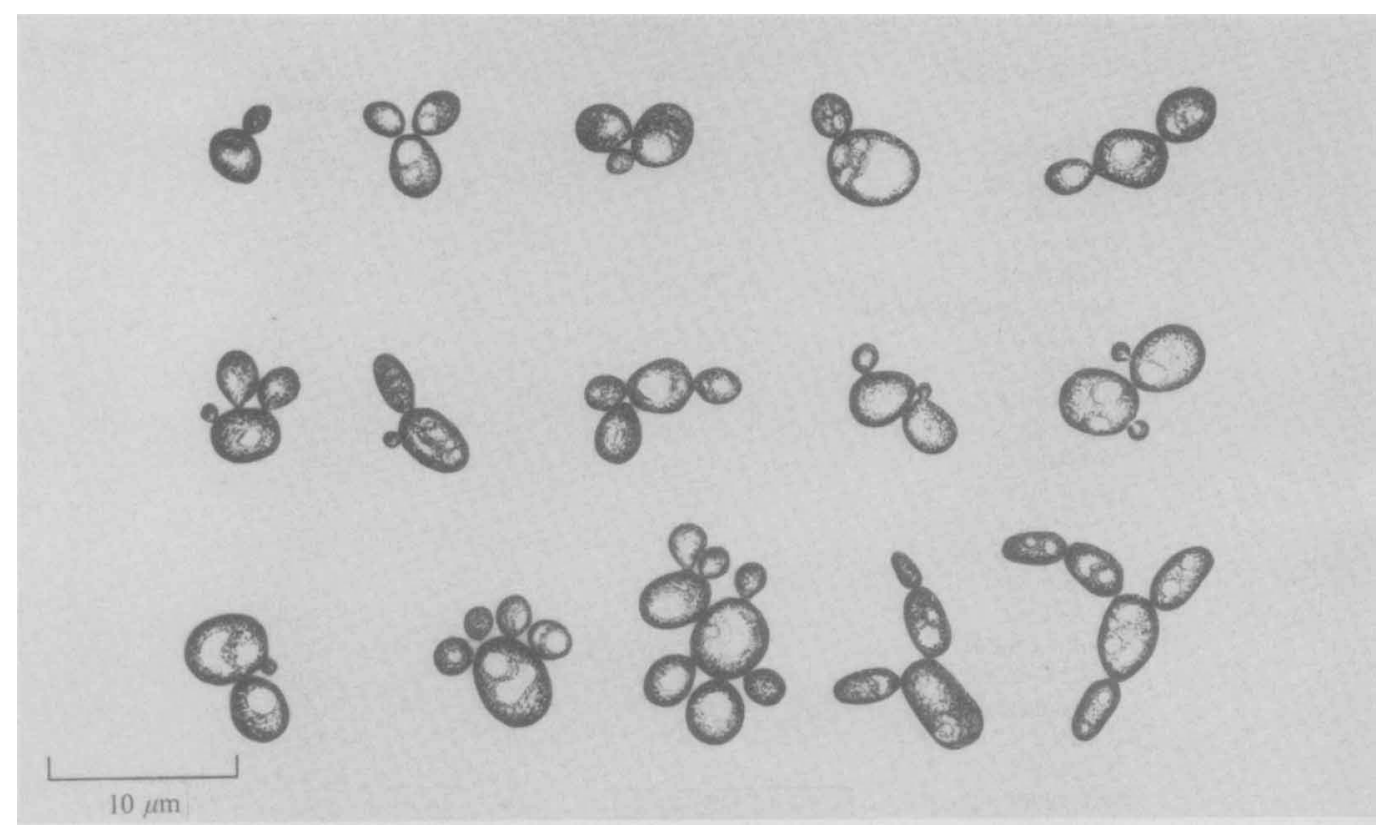

Fig. 4. Drawings of $T$. multis-gemmis made from several strains during exponential growth at $25^{\circ} \mathrm{C}$ in shaken defined liquid medium with $\mathrm{D}$-glucose as sole carbon source.

lente), succinato, citrato, glycerolo (lente), ribitolo, D-glucitolo. Non crescunt cum raffinoso, methyl $\alpha$-D-glucosido, cellobioso, salicino, melibioso, lactoso, L-rhamnoso, D-arabinoso, lactato, erythritolo, D-mannitolo, galactitolo, myo-inositolo, amylo, inulino. Kalii nitras non assimilatur. Vitaminarum addendum necessarium est. In $37^{\circ} \mathrm{C}$ non crescunt; in $30^{\circ} \mathrm{C}$ crescunt. In $50 \%$ D-glucoso non crescunt. Amylum non formatur. Urea non hydrolysatur. Arbutinum non finditur. Acidum formatur (exigue). Sebum bovillum finditur. Gelatinum non liquidum fit. n-Hexadecanum et n-decanum (tardum) assimilantur.

Typus cultura 6524 in collectione Centraalbureau voor Schimmelcultures, Delft, isolata ex Rubus idaeus.

\section{Cultural characteristics}

Macroscopical appearance. After 3 days at $25^{\circ} \mathrm{C}$, streak cultures on Difco Bacto YM agar and on malt agar were white or grey-white, matt or semi-glossy, smooth, soft, flat, with entire to undulating margins. After I month at $15{ }^{\circ} \mathrm{C}$, cultures were white, semi-glossy, soft, flat, with smooth margins and undulating to lobate borders.

Microscopical appearance. In exponential growth in liquid defined medium containing D-glucose the cells were spherical to ovoid, rarely short and cylindrical (Fig. 4). Cells measured $\mathrm{I} \cdot 8$ to $4.7 \times \mathrm{I} \cdot 6$ to $3.9 \mu \mathrm{m}$ (Table I). Cells on glucose-yeast extract-peptone-water medium appeared similar to those growing on malt extract medium and those on liquid defined medium, and occasionally pseudomycelium consisting of budding chains (Fig. 5a), together with cells with multiple buds (Fig. $5 b$ ) were formed. Single cells with up to 7 buds were sometimes seen. Cells in chain formation were often short and cylindrical.

On slide cultures of potato-dextrose agar and corn meal agar (Difco Bacto), pseudomycelium was absent or rudimentary, and consisted of a few short budding chains of oval 


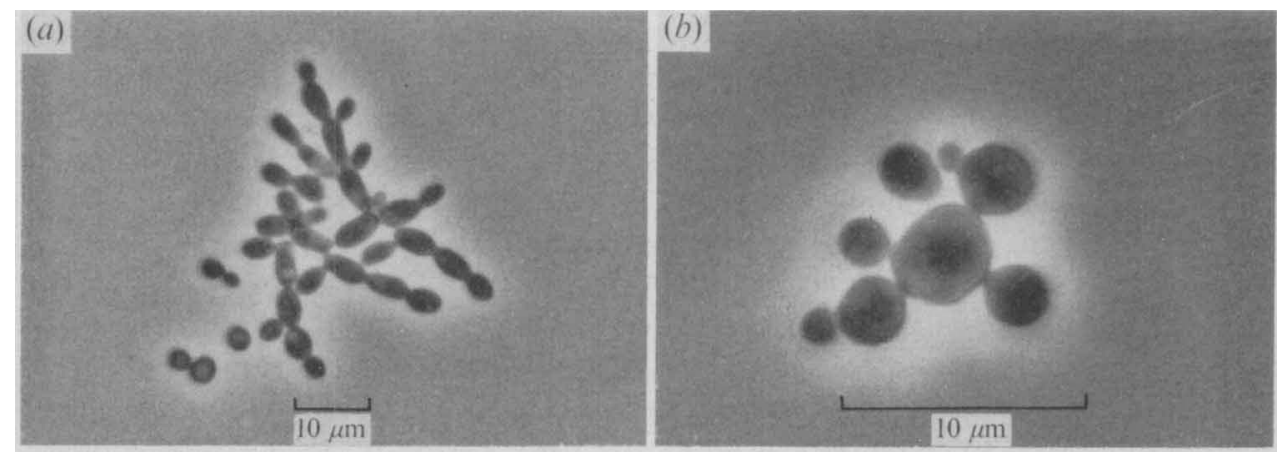

Fig. 5. Photomicrographs of T. multis-gemmis (CBs6524) showing rudimentary pseudomycelium $(a)$, and multiple budding $(b)$, in unshaken glucose-yeast extract-peptone-water after 3 days. Incubation was at $25^{\circ} \mathrm{C}$ throughout. Leitz phase contrast (Heine).

cells near the edge of the coverslip. No conjugation or ascospore formation was seen in individual strains or in mixtures of strains. Ballistospores were not formed.

\section{Physiological tests}

Anaerobic fermentation. With $50 \mathrm{~mm}$ D-glucose in yeast-water medium, little gas was produced in Durham tubes; fermentation was sometimes delayed for up to 2I days. None of the strains produced gas with raffinose, sucrose, maltose, trehalose, melibiose, lactose, or D-galactose.

Aerobic growth. Results are given in Table 2. Of the 20 strains tested, one strain did not grow with D-xylose. D-Ribose was utilized by all strains but only after a latent period of 20 to 30 days.

Other tests. The cells did not produce starch on liquid or solid media; urea was not hydrolysed; arbutin was not split; no pulcherrimin pigment was formed. On YM agar after 3 days, growth of all strains was abundant at $20^{\circ} \mathrm{C}$, sparse at $30^{\circ} \mathrm{C}$, and absent at $37^{\circ} \mathrm{C}$. The reaction of cells grown on $\mathrm{CaCO}_{3}$ acid production plates was weakly positive; fat was split, but not litmus milk; gelatin was not liquefied. The strains did not grow on media with $50 \%(w / v) ~ D-g l u c o s e$, but $n$-decane and $n$-hexadecane were both utilized as sole carbon sources although in the case of $n$-decane visible growth was delayed for up to ro days.

Two strains of T. multis-gemmis, CBS6524 (type strain) and CBS6525, have been deposited in the collection of the Yeast Division of the Centraalbureau voor Schimmelcultures. Both strains were isolated from raspberries.

\section{DISCUSSION}

Torulopsis bacarum and T. pustula follow the description of the genus Torulopsis Berlese (van Uden \& Vidal-Leiria, I970) in that they are asporogenous, non-filamentous, do not utilize inositol, do not form obvious carotenoid pigment, and reproduce solely by multilateral budding. Some strains of T. bacarum growing on agar medium are, however, lightly tinged with lilac. This tinge is characteristic of cultures of Taphrina growing saprophytically (Verona \& Rambelli, 1962). Taphrina, however, unlike $T$. bacarum, forms starch and does not utilize erythritol - both characters are at present taxonomically significant (Mix, I954; Lodder, 1970).

Some yeast genera form sterigmata, from which either ballistospores (Bullera, Sporo- 
bolomyces) or vegetative cells (Sterigmatomyces) arise. Torulopsis pustula, however, does not form ballistospores, and unlike Sterigmatomyces, the structures formed are more like blisters than sterigmata and moreover they do not occur with every bud. Commonly, two buds are attached to the structure, and when buds detach the mother cell is left with a prominent blister near the pole. Although $T$. pustula is typified by this method of bud formation, D. Yarrow (personal communication, I97I) states that similar bud formations occur with individual strains of Cryptococcus, Rhodotorula and Candida.

In addition to the negative characteristics described for $T$. bacarum and $T$. pustula, all strains of $T$. multis-gemmis characteristically produce cells with many buds. Morphologically, the cells of T. multis-gemmis resemble those of Torulopsis xestobii, a species isolated from insect sources by Jurzitza (1970), and both species form rudimentary pseudomycelium under similar conditions. Physiologically, however, the two species are readily differentiated on the basis of differences in the utilization of raffinose, melezitose, methyl $\alpha$-D-glucoside, cellobiose, melibiose, and sorbitol. Moreover T. xestobii lacks fermentative ability. In addition, there is a close similarity in the pattern of substrate utilization between T. multisgemmis and Candida parapsilosis (Ashford) Langeron \& Talice (van Uden \& Buckley, 1970) and its variety querci; however, the abundant pseudohyphae which typifies C. parapsilosis, together with its larger cell size, distinguishes these species.

Torulopsis multis-gemmis, C. parapsilosis and T. xestobii have the ability to use hydrocarbons as sole carbon sources. With $n$-hexadecane, C. parapsilosis (CBS604) and T. multisgemmis grow well and visible growth is present within 2 days of the test. With $n$-decane, C. parapsilosis similarly grows well whereas growth of $T$. multis-gemmis is sparse and delayed. In contrast, $T$. xestobii (CBS5975) utilizes both $n$-decane and $n$-hexadecane with difficulty, and growth is barely discernible within the test period.

Although T. multis-gemmis forms rudimentary pseudomycelium, this formation is always sparse. In slide cultures, pseudomycelium consists only of short budding chains of oval cells. This tendency to form filamentous growth is more marked in liquid media (see Methods), in which, after proliferating for up to one week, cells within the chain formations tend to elongate and limited branching takes place. The significance of a limited or primitive formation of pseudomycelium has in the past been open to much debate. Lodder (1934) used the presence of the 'appareil sporifère' (Langeron \& Talice, 1932) to distinguish between the two subfamilies Torulopsidoideae and Mycotoruloideae, but later changed this criterion to include 'all forms of concrescence of elongated cells' within the genus Candida (Lodder \& Kreger-van Rij, 1952). The same authors also acknowledged the existence of transitional forms between the genera Torulopsis and Candida. Torulopsis multis-gemmis, however, does not qualify for a place within the genus Candida Berkhout according to the criteria laid down by van Uden \& Buckley (1970) who state that 'the separation of Torulopsis from Candida is based [in] the capacity to form pseudomycelium, absent or poorly developed in the former, well developed in the latter'. Thus the degree of pseudomycelial development is open to individual interpretation and allows species with limited pseudomycelial ability to be included in non-filamentous genera (e.g. Torulopsis candida). However, it must be borne in mind that pseudomycelium may be markedly influenced by external factors (Lodder \& Kreger-van Rij, 1952), and strict adherence to the slide culture procedures may have the effect of masking the filamentous nature of some species. More emphasis could be put on routine examination for filamentous growth in liquid media together with an extended incubation time.

The specific name for Torulopsis bacarum (Latin baca $=$ berry) refers to the various types of edible berries from which the species was isolated. The specific name for Torulopsis 
pustula (Latin pustula = blister) describes the structure often formed by the cells of that species, and that of Torulopsis multis-gemmis is derived from the Latin multi = many, and gemma $=$ bud.

I thank Dr J. L. Peel for criticisms of the manuscript, Mr M. J. Brown for his invaluable photographic help, Dr D. Yarrow of the Centraalbureau voor Schimmelcultures for his advice and confirmation of the three new species, and Mrs H. A. Belcher for her expert technical assistance.

\section{REFERENCES}

BARNETT, J. A. \& BUHAGIAR, R. W. M. (I97I). Torulopsis fragaria species nova, a yeast from fruit. Journal of General Microbiology 67, 233-238.

BuhagiaR, R. W. M. \& BARNETt, J. A. (1971). The yeasts of strawberries. Journal of Applied Bacteriology 34, 727-739.

JURZITZA, G. (1970). Über Isolierung, Kultur und Taxonomie einiger Anobiidensymbionten (Insecta, Coleoptera). Archiv für Mikrobiologie 72, 203-222.

LANGERon, M. \& TAlice, R. V. (1932). Nouvelles méthodes d'étude et essai de classification des champignons levuriformes. Annales de parasitologie humaine et comparée 10, I-80.

LODDER, J. (1934). Die anaskosporogenen Hefen, erste Hälfte. Verhandelingen der K. akademie van wetenschappen (2 sectie) 32, I-256.

LodDer, J. (1970). The Yeasts. A Taxonomic Study. Amsterdam: North-Holland Publishing.

Lodder, J. \& Kreger-van RiJ, N. J. W. (1952). The Yeasts. A Taxonomic Study. Amsterdam: NorthHolland Publishing Co.

Markovetz, A. J. \& Kallio, R. E. (1964). Assimilation of alkanes and alkenes by yeasts. Journal of Bacteriology 87, 968-969.

Mrx, A. J. (1954). Differentiation of species of Taphrina in culture. Utilization of carbon compounds. Mycologia 46, 721-727.

Phaff, H. J., Miller, M. W. \& Mrak, E. M. (1966). The Life of Yeasts. Massachusetts: Harvard University Press.

Ross, S. S. \& Morris, E. O. (1965). An investigation of the yeast flora of marine fish from Scottish coastal waters and a fishing ground off Iceland. Journal of Applied Bacteriology 28, 224-234.

van Uden, N. \& Buckley, H. (1970). Candida Berkhout. In The Yeasts. A Taxonomic Study. Edited by J. Lodder. Amsterdam: North-Holland Publishing.

van Uden, N. \& Vidal-Leiria, M. (1970). Torulopsis Berlese. In The Yeasts. A Taxonomic Study. Edited by J. Lodder. Amsterdam: North-Holland Publishing.

VAN DER WALT, J. P. (1970). Criteria and methods used in classification. In The Yeasts. A Taxonomic Study. Edited by J. Lodder. Amsterdam: North-Holland Publishing.

Verona, O. \& RAMbelli, A. (1962). Notizie intorno ai caratteri di alcune specie di Taphrina in fase saprofitaria (Saprotaphrina). Annali della facoltà di agraria della Università di Pisa 23, I-36. 